\title{
ПРОБЛЕМЫ ИСТОРИИ
}

DOI: $10.15372 / \mathrm{HSS} 20150407$

УДК 94(470.67)

М.-П.Б. АБДУСАЛАМОВ, Н.Д. ЧЕКУЛАЕВ

\section{ИЗ ИСТОРИИ ПЕРСИДСКОГО ПОХОДА ПЕТРА І: БИТВА ПОД ЭНДИРЕЕМ 1722 г.}

\author{
Магомед-Паша Балашович Абдусаламов, \\ канд. ист. наук, доцент, \\ Дагестанский государственный институт народного хозяйства, \\ РФ, 367008, Махачкала, ул. Атаева, 5 \\ e-mail: vikingpasha@mail.ru \\ Николай Дмитриевич Чекулаев, \\ канд. ист. наук, научный сотрудник, \\ Институт истории, археологии и этнографии ДНЦ РАН, \\ РФ, 367030, Махачкала, ул. Ярагского, 75 \\ e-mail: bratzikow1974@mail.ru
}

В статье на основе анализа разнообразных источников и литературы рассматривается один из малоизученных, трагических эпизодов Персидского похода Петра I - битва под Эндиреем 1722 г. Освещаются малоизвестные факты Эндиреевского сражения, дается их оценка. Показывается взаимодействие правительства Петра I с различными кумыкскими феодальными правителями. Раскрываются причины выступления эндиреевцев против армии Петра I.

Ключевые слова: Россия, Персидский поход, Петр I, Кумыкия, междоусобицы, шамхальство Тарковское, Эндирей, битва, казаки.

M.-P.B. ABDUSALAMOV, N.D. CHEKULAEV

FROM THE HISTORY OF THE PERSIAN CAMPAIGN OF PETER I: BATTLE OF ENDIREEM, 1722

\author{
Magomed-Pasha Balashovich Abdusalamov, \\ Candidate of Historical Sciences, Associate Professor, \\ Dagestan State Institute of National Economy, \\ 5, Atayeva St., Makhachkala, 367008, Russia, \\ e-mail: vikingpasha@mail.ru \\ Nikolai Dmitrievich Chekulaev, \\ Candidate of Historical Sciences, Researcher, \\ Institute of History, Archeology and Ethnography, \\ Dagestan Scientific Center of the RAS \\ 75, Yaragskogo St., Makhachkala, 367030, Russia, \\ e-mail: bratzikow1974@mail.ru
}

\footnotetext{
The purpose of this article is not only to describe the events associated with armed clashes between the Russian troops and the highlanders near the village of Endirey, but also to reveal the causes of this negative event in the history of Russian-Dagestan relations based on the available archival documents. In addition, attention is paid to the relationships of Russia with several Kumyk feudal rulers.
} 
In July 1722 the Emperor Peter the Great and his army entered the territory of Dagestan. However, the beginning of the company was not easy. The Russian army began to suffer losses long before the first clash with the enemy: 150 soldiers died from diseases in Astrakhan, while 40 soldiers escaped. The cavalry crossing the North Caucasian steppe was behind the original schedule. As envisioned by the tsar, the dragoons would arrive in the Agrakhan Gulf sooner than the infantry traveling by sea in order to ensure the landing operation with the construction of piers and to provide cover against possible enemy attacks. All such orders were given by Peter to Brigadier Andrey Veterani on July, 7.

The cavalry, however, could not meet the deadline. G.S. Kropotov with his regiments made a forced crossing of the Volga river near the town of Selitrennoye only on July, 5 but in the next three weeks he still could not reach the Terek. On July, 30 he reported that he was encamped at "Kizlyar Lake" and could not move faster: "Dragoon horses are rather thin due to long marching across the great steppes, poor quality of forage and most of all due to heat and salt water".

The corps of Veterani moving from Tsaritsyn crossed the Terek on July, 16-17 and had to wait until gunpowder and lead were delivered from the Terskiy town. Thus, Veterani as a commander notified the tzar that he would be able to move on only in the night of July, 21 . In the same report the Brigadier informed of other bad news: Ukrainian Cossack colonel Apostle while following after him found himself in the middle of the "burnt steppe", facing the loss of horses and lack of forage.

Veterani was to take Andreevskaya village (village of Endirey) and to ensure the landing operation in the Agrakhan Gulf. He was joined by the prince of Greater Kabarda Elmurza Cherkassky (the lieutenant in the Russian service, the younger brother of the deceased in Khiva A. Cherkassky) and the prince of Minor Kabarda Aslambek Kommetov. Endirey rulers Aydemir and Chopan-Shamhal tried to resist and attacked the regiments marching near the village. After a fierce battle on the 23th of July, the dragoons broke through to Endirey and destroyed it, having lost 89 people dead and 115 wounded.

In conclusion the authors identify the causes that led to the battle between the Russian army and highlanders near the village Endirey

Key words: Russian, Persian campaign, Peter I, Kumykia, feuds, Shamkhalate of Tarki, Endirey, battle, the Cossacks.

Персидский поход Петра I являлся важной вехой в истории русско-дагестанских отношений. О походе Петра I в Прикаспий писали историки дореволюционного и советского периодов, немало работ по данной теме издано за последние двадцать лет. Все это свидетельствует о глубоком интересе исследователей к данной проблеме. Вместе с тем, отдельные ее стороны либо не нашли должного отражения в публикациях ученых-историков, либо вообще ими не затронуты. Нами будут рассмотрены причины одного из самых драматичных и малоисследованных эпизодов Персидского похода Петра I - кровопролитной битвы под Эндиреем 1722 г.

Накануне Персидского похода Петра I политическая обстановка в Кумыкии, как и в Дагестане в целом, не была стабильной. Земля кумыков была раздроблена на ряд более или менее крупных владений: шамхальство Тарковское, княжества Засулакской Кумыкии - Эндиреевское, Аксаевское и Костековское и др. $[1$, c. 74$]$

В первой четверти XVIII в. по-прежнему продолжались междоусобицы кумыкских владетелей за шамхальский престол. Разгорелась очередная ожесточенная борьба между шамхалом Адиль-Гиреем Тарковским, с одной стороны, и его братьями Муртазали и Умалатом Казанищенским - с другой. Последние пользовались поддержкой персидского шаха, АдильГирей же обратился за поддержкой к Петру I. АдильГирей писал в 1717 г.: «Я, прибегая к Вашему милосердию, нижайше, всепокорнейше прошу, чтоб и великим своим указом повелели астраханскому и терскому управителям в нуждах наших, как в военные, так и в других случаях помогать...» [2, с. 311]. Петр I такой указ издал. В нем говорилось: «Тебе, Адиль-Гирей, под оборону нашу и подданство принимаем, ради чего даны указания нашим губернатору астраханскому и коменданту терскому защищать, и в случае нужды и помогать» [2, с. 311].
Таким образом, в 1718 г. шамхал Адиль-Гирей, сын Муртазали, вступает в подданство России [3, c. 57].

20 апреля 1719 г. астраханский губернатор А.П. Волынский доносил в Коллегию иностранных дел: «Кумыкский народ, хотя и под персидскою протекцией, однако ж надеются, если приложить труд, то будет доброжелательное к нам, а между и народом силу имеет владетель Тарковский Адиль-Гирей... Если изволите его удовольствовать и дать ему для охранения Тарков одну роту солдат, о чем он сам просит, также и жалованье ему денежного и хлебного прибавить» [4, c. 139].

Просьба А.П. Волынского была удовлетворена из Тарков к шамхалу отправили команду из 15 солдат и три пушки ${ }^{1}$.

Эндиреевские владетели поставили в известность Петра I, что они не согласны с тем, что шамхалом Тарковским стал Адиль-Гирей. Об этом писал князь Чопан-шамхал Эндиреевский князю А. Бековичу Черкасскому 25 ноября 1719 г.: «<..> шамхал преставился, то кизилбаш (т.е. шах Ирана) Адиль-Гирея шамхалом сделал и мы сему “не контенты” (в переводе с английского - недовольны. - М.-П.А., Н.Ч.) [5, с. 91].

При этом каждый из претендентов обращался к российским властям, обвиняя своих недругов в измене России. Шамхал Тарковский Адиль-Гирей писал Петру I о враждебности к нему кумыкских владетелей, а те в письмах царю говорили о том, что Адиль-Гирей был подданным турецкого султана и персидского шаха и ориентировался на них [2, с. 311].

Об этом, в частности, свидетельствует письмо Адиль-Гирея, с которым он обратился в 1717 г. к Петру I. В нем Адиль- Гирей старался убедить императо-

${ }^{1}$ Рукописный фонд Института истории, археологии и этнографии Дагестанского научного центра Российской Академии наук (РФ ИИАЭ ДНЦ РАН). Ф. 1. ОП. 1. Д. 454. Л. 157. 
ра, что его противники - эндиреевские владетели Мулхат и Чопан-шамхал - являются также врагами России. Этого же вопроса шамхал Тарковский касался и в своем донесении Петру I от 20 апреля 1719 г. Здесь он уже прямо писал, что «выгнал из Тарков Молата-шамхала, из Эндиреевой деревни князя Чобан-шамхала, и брата своего родного большого Муртазали, которые держали партии персидского шаха» [5, с. 91].

Аналогичные сведения об эндиреевских владетелях доносил Петру I и другой владетель - Султан-Махмуд Аксаевский в своем письме от 1-6 августа 1722 г., который также враждовал с Чопан-шамхалом ${ }^{2}$.

В 1717 г. в своем письме Петру I кумыкский шамхал Адиль-Гирей (а позднее аксаевский владетель Султан-Махмуд в вышеназванном своем письме от 1-6 августа 1722 г.) сообщал, что «казаки, которые ему изменили и непослушны были и в рубежах наших при Эндиреевском Мулхате, бывшего хана сына, да Чопан-шамхале приезжали, были во охранении его, и я уведомился о измене их, что они вам противники, с войском своим из оных 34 человек поймав, 4 человека отправил в Терки, а остальные всех убил, того ради помянутой Мулхат и Чопан-шамхал жаловались персидскому шаху на меня и объявили ему, что я от него, шаха, отложился и к вам, российскому государю, поддался и службу принял и их учинился противен я, он, шах, отнял у меня выплачиваемое мне денежное жалованье» [6, с. 226].

Известно, что еще в конце XVII в. после подавления народных движений в России тысячи русских людей, спасаясь от казней, устремлялись на Северный Кавказ, в том числе и на берег Терека и Сулака. Здесь создавались целые городки и опорные базы восставших. Некоторые известные «разбойничьи» атаманы, такие как Костька Иванов и другие, действовали среди чеченцев и кумыков в начале XVIII в. В отместку на казаков-бунтовщиков и раскольников-еретиков и их союзников горцев совершались карательные экспедиции. В 1700 г. было принято решение послать войско на Муртазали и «воровских» казаков.

Совместными усилиями царских войск и феодальных соперников Муртазали повстанческим силам был нанесен серьезный удар. Полковник Бушев с гребенскими казаками захватил атамана Костьку «с немалым числом его артели» в укрепленном городке близ Сулака и отправил его в Астрахань, где он был казнен. С другой стороны, шамхал Адиль-Гирей с Султан- Махмудом Аксаевским двинулись на Муртазали, отказавшегося выдать казаков (находившихся непосредственно при нем), и разбили его. Часть русских беглых погибла в бою, другие попали в плен и были отправлены в Терки. Так как русские беглые люди находились и во владении другого кумыкского владельца - Чопан-шамхала, то он тоже был разбит. Имелись данные, что Муртазали и Чопан-шамхал были изгнаны из своих «юртов» и скрывались в горах [7, с. 315, 362].

Российские власти из переписки с Адиль-Гиреем шамхалом получали о эндиреевских владетелях нега-

\footnotetext{
${ }^{2}$ РФ ИИАЭ ДНЦ РАН. Ф. 1. Оп. 1. Д. 60. Л. 211-212.
}

тивные сведения. Сам Адиль-Гирей не скрывал, что хочет посадить своего сына Хасбулата владетелем Ауха (который с XVI в. был под контролем эндиреевских князей) [8, с. 67].

А.П. Волынский доносил 2 сентября 1721 г., что эндиреевский владетель Муцал Чапалов приезжал в Астрахань с тем намерением, чтобы он стал управителем Терского города, но он отказал Муцалу в удовлетворении его требования. Далее А.П. Волынский доносил в Коллегию иностранных дел: «А что в указе Его Царского Величества упомянуто, чтоб мне о оных эндиреевских владетелях разведать, можно ли от них уповать какой пользы интересу Его Царского Величества, однако же я ничего не могу уповать и содержать разве для того, чтоб не были на той стороне и обще не чинили бы с противными Терку и гребенским казакам пакости. А польза или обороны никогда никакой не будет» ${ }^{3}$

Междоусобная борьба закончилась победой Адиль-Гирея Тарковского. 23 января 1721 г. в своем письме к канцлеру графу Головину он писал: «Доношу вам великому государю понеже я рабов ваших раб получил шамхальство горское счастие вашего великого государя и непредь чего о чем я просил у вас великого государя, то все получили и ненавидящие мои противники, видя от вас великого государя ко мне показанную милость, в большую ненависть впали и стали домогаться всякими худыми делами обносить, того ради прошу вас великого государя дабы таким моим противникам и их доношениям без подлинного изъяснения не верить» ${ }^{4}$

Данный документ красноречиво свидетельствует, что Адиль-Гирей, умело используя сложившуюся ситуацию в Кумыкии, своими интригами сумел не только победить своих соперников в борьбе за Тарковское шамхальство, но и приложил все усилия, чтобы у Петра I сложилось отрицательное мнение об эндиреевских владетелях. Таким образом, можно утверждать, что шамхал Адиль-Гирей своими действиями спровоцировал эндиреевский инцидент.

Вслед за шамхалом и Султан-Махмудом Аксаевским к России с просьбой о вступлении в российское подданство обратились эндиреевские владетели. В своем письме к Петру I от 24 апреля 1720 г. эндиреевские князья заявили о готовности быть на русской службе. Эту просьбу они повторили в своем письме от 24 февраля 1721 г. Вскоре Петр I удовлетворил их просьбу и принял в российское подданство [9, с. 111].

Однако правители Эндирея, вступившие в российское подданство, продолжали нападать на гребенские городки и Терки.

В ноябре 1720 г. эндиреевские владетели Айдемир Хамзин и шамхал Чопан против Терков и гребенских городков «явную войну начали», в результате которой с ноября 1720 г. по май 1721 г. русские потеряли убитыми, ранеными и взятыми в плен 139 чел. Кроме

${ }^{3}$ РФ ИИАЭ ДНЦ РАН. Ф. 1. ОП. 1. Д. 59. Л. 134.

${ }^{4}$ Там же. Д. 60. Л. 91. 
того, были взяты в плен свыше 3 тыс. чел. «иноверцев» и 30 дворов терских татар; количество отогнанного скота составляло 2 тыс. голов и 950 кибиток.

По распоряжению астраханского губернатора против эндиреевских владетелей были посланы терские и донские казаки, которые осенью 1721 г. произвели рейды к рекам Астрахани и Аксай, причинив противнику потери в 110 чел. и отогнав у него свыше 5000 голов скота [6, с. 256-257, 296].

Эндирей, по словам астраханского губернатора А.П. Волынского, - это «яко гнездо разбойническое, от которого претерпевали всегдашнее нападение как и окрестной страны жители, так и все проезжающие». Вот как об этом доносил И.-Г. Гербер: «Великая сил деревня лежит в Дагестане между реками Сулаком и Аксаем, промеж гор и лесов, к которой и другие около лежащие малые деревни принадлежат. Она, обогатившись грабительством и укрепившись на твердом от натуры месте, так страшною учинилась через свои набеги, что не только соседи ее не смели выгонять скот на пастьбу, но больше гребенских казаков и терских жителей через покражу лошадей и скотины обижали, но и ходящие из Астрахани в Шемаху купеческие караваны часто от жителей оных были разбиваемы и разграбляемы, и все проезжие дороги опасными от них учинилось, что происходило до самого при сем случае деревни сей разорение и купцы были принуждены торг сухим путем оставить» $[10$, с. 69$]$.

Кроме того, эндиреевские владетели, занятые распрями с кабардинскими князьями, поставили себя в непростые отношения с Россией. Так, 23 февраля 1714 г. канцлер Г.И. Головин в своем письме к князю А.Б. Черкасскому уведомляет о том, что царь направляет своего посланца к кумыкскому и эндиреевскому владетелям с требованием не производить нападения на кабардинцев [11, с. 64].

Следует учитывать и то, что эндиреевские феодалы придерживались протурецкой ориентации, которая усилилась в связи с высадкой в июле 1722 г. армии Петра I в Дагестане, означившей начало Персидского похода российского императора. Возросла активность Порты, которая приняла меры, чтобы противостоять устремлениям Петра на Кавказе. Подкупом и интригами местных владетелей Турция стремилась не допустить русские войска на территорию Дагестана [12, с. 191]. Сами эндиреевские владетели не хотели мириться с господством России в Северной Кумыкии. Кроме того, одной из причин того, что эндиреевский владетель Айдемир оказал сопротивление армии Петра I, были беспрестанные разбои и нападения в 1721 г. на Терки [13, с. 13].

Выступление рядовых эндиреевцев против многотысячной регулярной российской армии было актом людей сильной воли, не пожелавших потерять свою независимость и подчиниться российскому императоpy [14, c. 209].

Военные действия начались в июле 1722 г. Конный корпус под командой бригадира Ветерани имел задачу - атаковать и взять Эндирей, «отомстив за мно- гие набеги причиненные русским подданным», выйти к устью р. Аграхани и оборудовать небольшие «пристани» на берегу Аграханского залива, куда из Астрахани должна была прийти Каспийская флотилия для высадки пехоты, и обеспечить безопасность десантной операции [9, с. 120-121].

Бригадир Ветерани, войдя с тремя драгунскими полками и 400 казаками без всяких предосторожностей в лесистое ущелье, ведущее к бывшей Эндиреевский крепости (у деревни Эндирей), подвергся нападению горцев, засевших в горах и на деревьях [15, с. 426].

Когда жители узнали о движении в их сторону 80 -тысячного конного войска, то решили, что причина этому - набег эндиреевцев в прошлом году на слободы и окрестности русской крепости Терек, за которые теперь эта армия хочет их наказать. Тогда они в отчаянии 23 июля атаковали драгун далеко в степи, стремясь этим не пустить войско к Эндирею, но этим лишь навлекли на себя основные силы конницы со всеми дальнейшими последствиями. Подполковник Наумов тут же поспешил на помощь драгунам. Наверное, своевременные переговоры могли бы предотвратить это печальное событие, но эндиреевцы почему-то не выслали гонцов (видимо, считали, что все и так ясно), а русские и до их атаки имели сведения об протурецких настроениях главы здешних князей Чопане от Тарковского шамхала Адиль-Гирея [8, с. 67].

Когда бригадир Ветерани 23 июля приблизился к деревне, 5 тыс. эндиреевцев обстреляли россиян пулями и стрелами. В этот момент войско находилось в самом узком месте дороги и потому оказалось в западне. Вместо того, чтобы скорее покинуть опасный участок, бригадир приказал нескольким ротам спешиться и начать обороняться.

Положение горцев было более выгодным, и лишь с большим трудом, потеряв 70 драгун убитыми и несколько десятков ранеными, Ветерани, сломив сопротивление эндиреевцев, вошел в деревню. 300 местных жителей были убиты на месте, остальные бежали в горы, где горцы были в безопасности. В деревне, состоявшей из 300 дворов, была взята богатая добыча, а сама деревня сожжена.

Видимо, впоследствии бригадиру Ветерани удалось оправдаться, потому что из различных источников известно, что он всегда командовал передовым войском армии $[16$, с. 570$]$.

После этого Ветерани с армией вернулся, а вскоре к нему присоединился и генерал-майор Кропотов с драгунами; 10 тыс. донских и малороссийских казаков под командованием атамана Краснощекова и других старшин прибыли примерно 2 августа; одновременно прибыли и 5 тыс. калмыков от хана Аюки. 4 августа государь дал указ приставу при них, гвардии поручику Нефеду Кудрявцеву, чтобы тот шел с калмыками к Эндирею и нашел оставшихся эндиреевцев. В августе действительно произошел опустошительный набег калмыков на эндиреевцев. Как обычно, калмыки, не зная меры, отбили у жителей деревни баранов, быков и лошадей, после чего расположились у гребенско- 
го Курдюкова городка. Государь пожаловал им 10 тыс. руб. Эндиреевцы, раскаявшись, прислали к Петру I посланцев, «прося прощения и принося свое подданство, на которое и дали присягу, включив в оное, еще в первый раз, и подданных своих чеченцев». Поэтому государь позволил им пока жить в Эндирее, но не строить укреплений. Никакой данью они обложены не были. Для наблюдения за эндиреевцами бригадиру Шамандину 28 сентября 1722 г. был дан указ расположиться с корпусом его против Эндирея. Вместе с ним должен был быть гвардии поручик Кудрявцев с калмыками $[17$, с. $22-23]$.

Таким образом, на основании вышеизложенного, мы считаем, что причинами битвы под Эндиреем явились:

1) политика шамхала Адиль-Гирея, который в союзе с Султан-Махмудом Аксаевским, ведя междоусобную борьбу за шамхальский престол, сумел своими интригами добиться того, чтобы у Петра I сформировалось негативное отношение к эндиреевским владетелям, укрывавшим, как следовало из доносов АдильГирея, «воровских» людей;

2) многочисленные грабительские набеги кумыков на Терки и казачьи городки, купеческие караваны;

3) вражда с союзниками России на Кавказе - кабардинскими князьями;

4) происки Порты, засылавшей своих агентов в Кумыкию с целью поднять кумыков против России;

5) выступление рядовых эндиреевцев, которые, не жалея собственной жизни, выступили на защиту своей независимости.

\section{СПИСОК ЛИТЕРАТУРЫ}

1. Абдусаламов М.-П.Б. Кумыкские феодальные владения в политической жизни Дагестана в первой половине XVIII века. Махачкала: Изд. дом «Народы Дагестана», 2008. 192 с.

2. Русско-дагестанские отношения в XVIII - начале XIX вв. сб. док. / отв. ред. В.Г. Гаджиев. М.: Наука, 1988. 357 с. C. $53-80$.

3. Шамхалы Тарковские // ССКГ. Тифлис, 1868. Вып. I.

4. Гусенов М.У. Шамхальство Тарковское в системе феодальных государственных образований на Северном Кавказе в XVII нач. ХІХ вв.: дисс... канд. ист. наук. Махачкала, 1996. 167 с.

5. Гаджиев В.Г. Сочинения И. Гербера «Описание стран и народов между Астраханью и рекой Курой, находящихся» как исторический источник по истории народов Кавказа. М.: Наука, 1979. 270 с.

6. Русско-дагестанские отношения XVII - первой четверти XVIII вв.: док. и материалы / сост. Р.Г. Маршаев. Махачкала: Дагкнигоиздат, 1958. $336 \mathrm{c}$.

7. Ахмадов Я. История Чечни с древнейших времен до конца XVIII в. М.: Изд-во «Мир дому твоему», 2001. 426 с.

8. Магомедов Р.М. Даргинцы в дагестанском историческом процессе. Махачкала: Дагкнигоиздат, 1999. Кн. II. 520 с.

9. Лысияов В.П. Персидский поход Петра I. 1722-1723 гг. М.: Изд-во МГУ, 1951. $247 \mathrm{c}$

10. Гербер И.-Г. Описание стран и народов вдоль западного берега Каспийского моря. 1728 г. // ИГЭД. М.: Изд-во вост. лит., 1958. C. $60-120$.

11. Сотавов Н.-П.А. Крах «Грозы Вселенной». Махачкала: Респ. газ.-журн. типография, 2000. 223 с.
12. Магомедов Р.М. История Дагестана. С древнейших времен до конца ХIX в. Махачкала: Дагучпедгиз, 1968. 340 с.

13. Неверовский A.A. Краткий исторический взгляд на Северный и Средний Дагестан до уничтожения влияния лезгинов на Закавказье. СПб.: Тип. воен.-учеб. завед., 1848. 42 с.

14. Магомедов P.М., Магомедов А.Р. История Дагестана. Махачкала: Дагкнигоиздат, 1994. 272 с

15. Пушкин А.С. Полн. собр. соч. М.: Наука, 1965. Т 9: История Петра. 460 с

16. Комаров В.В. Персидская война 1722-1725 гг. (материалы для истории царствования Петра Великого) // Русский вестник. М. Тип. Катков и Кㅇ 1867. Кн. 4. т. 68. С. 553-616.

17. Бутков П.Г. Материалы для новой истории Кавказа с 1722 по 1803 год: в 3 ч. СПб.: Тип. Имп. АН, 1869. Ч. I. 548 с.

\section{REFERENCES}

1. Abdusalamov M.-P.B. Kumyk fiefs in the political life of Dagestan in the first half of the XVIII century. Makhachkala: Narody Dagestana", 2008, 192 p. (In Russ.)

2. Russian-Dagestani relations in XVIII and early XIX centuries: a Collection of documents / ed. V.G. Gadzhiev. Moscow: Nauka, 1988, 357 p. (In Russ.)

3. Shamkhals of Tarki. SCG. Tiflis, 1868, vol. I, pp. 53-80 (In Russ.)

4. Housenov M.W. Shamkhalate of Tarki in the system of feudal states in the North Caucasus in the XVII and early XIX centuries Dissertation... kand. Hist. Sciences. Makhachkala, 1996, 167 p. (In Russ.)

5. Gadzhiev V.G. I. Gerber's Work "Description of the countries and peoples located between Astrakhan and the Kura river" as a historical source on the history of the peoples of the Caucasus. Moscow: Nauka, 1979, 270 p., ill., cards. Fox. (In Russ.)

6. Russian-Dagestani relations of the XVII and the first quarter of the XVIII century: Documents and materials / ed. R.G. Marchev. Makhachkala: Dagknigozdat, 1958, 336 p. (In Russ.)

7. Akhmadov $Y$. History of Chechnya from the earliest times to the end of the XVIII century, Moscow: "Mir tvoemy domy", 2001, 426 p. (In Russ.)

8. Magomedov R.M. The Dargwa in the historical process of Dagestan. Makhachkala: Dagknigoizdat, 1999, book. II. 520 p. (In Russ.)

9. Lystzov V.P. Persian campaign of Peter I. 1722-1723, Moscow: MSU Publishing House, 1951. 247 p.

10. Gerber I.G. Description of the countries and peoples along the Western shore of the Caspian sea. 1728. IGAD. Moscow: Publishing House of the East. literature, 1958, pp. 60-120 (In Russ.)

11. Sotavov N.-P.A. The Collapse of the "Storm of The Universe". Makhachkala: the Republican newspaper and magazine type, 2000, 223 p. (In Russ.)

12. Magomedov R.M. History of Dagestan. From ancient times to the late XIX century Makhachkala: Daguchpedgis, 1968, 340 p. (In Russ.)

13. Neverovsky A.A. Brief historical perspective on Northern and Central Dagestan before elimination of influence of Lezgians in the Caucasus. SPb.: Type. military.-proc. zaved., 1848, 42 p. (In Russ.)

14. Magomedov R.M., Magomedov A.R. History of Dagestan. Makhachkala: Dagknigozdat, 1994, 272 p. (In Russ.)

15. The A.S. Pushkin. Complete works. History of Peter. Moscow: Nauka, 1965, vol. 9, 460 p. (In Russ.)

16. Komarov V.V. Persian war of 1722-1725 (Materials for the history of the reign of Peter the Great). Russkij vestnik. Moscow: Rinks and Co., 1867, book. 4, vol. 68. p. 553-616. (In Russ.)

17. Butkov P.G. Materials for a new History of Caucasus from 1722 to 1803 : In 3 parts. SPb.: Typography of the Imperial Academy of Sciences, 1869 , part I, 548 p. (In Russ.)

Статья принята редакиией 22.10.2015 